\title{
PERAN MANAJEMEN DALAM BIMBINGAN PENYULUHAN ISLAM
}

\author{
Hamdi Abdul Karim \\ Institut Agama Islam Negeri (IAIN) Metro \\ Jl. Ki Hadjar Dewantara 15 A Kota Metro Lampung 34111 \\ Hamdiabdulkarim@yahoo.co.id
}

\begin{abstract}
Islamic guidance counseling management discusses how management is carried out by extension agents in carrying out their duties, including preparing education activities starting from determining the schedule and location of activities, organizing carried out by extension agents, of course, with the job description set up until the extension activities and stages evaluation to see the extent to which the success of the program activities that have been carried out with the aim of repairs. Planning in Islamic Counseling Guidance is the selection or determination of organizational goals in this case Counseling in Offices and certain institutions to determine strategies, policies, projects, programs, procedures, methods, systems, budgets and standards needed to achieve goals. In planning is also a plan or plan of activities that will be carried out within a certain period of time. The design or plan of the activity is arranged in a systematic, organized, and coordinated manner over a period of time, so that the implementation of extension activities goes well.
\end{abstract}

Keywords: Role, Management, Islamic Extension Guidance 


\section{A. PENDAHULUAN}

Pelayanan bimbingan penyuluhan Islam perlu dilakukan secara optimal sehingga pelayanan bimbingan penyuluhan Islam benar-benar memberikan kontribusi yang nyata bagi pencapaian visi, misi, dan tujuan dari pelayanan yang bersangkutan. Suatu program pelayanan bimbingan penyuluhan Islam tidak mungkin akan tersusun dan terselenggara dan tercapai apabila tidak dikelola dalam suatu sistem manajemen yang bermutu.

Manajemen yang bermutu sendiri akan banyak ditentukan oleh kemampuan manajer atau pengelola pelayanan Bimbingan Penyuluhan Islam (BPI) dalam merencanakan, mengorganisasikan, mengarahkan, dan mengendalikan sumber daya yang ada. Pelaksanakan manajemen bimbingan penyuluhan Islam harus dirumuskan secara matang baik dari segi program pelayanan BPI, meneliti hal-hal apa sajakah yang dibutuhkan oleh objek, materi-materi yang harus disampaikan untuk membentuk kematangan, satuan layanan dan kegiatan dalam bimbingan penyuluhan islam, serta dapat merumuskan dengan baik tatalaksana bimbingan penyuluhan islam, dan mengevaluasi program yang telah dilaksanakan.

Manajemen bimbingan penyuluhan Islam juga membahas tentang bagaimana pengelolaan yang dilakukan oleh penyuluh dalam melaksanakan tugasnya, diantaranya dalam melakukan persiapan kegiatan penyuluhan mulai dari penentuan jadwal dan lokasi kegiatan, pengorganisasian yang dilakukan oleh penyuluh tentunya dengan job description yang sudah diatur hingga sampai pada pelaksanaan kegiatan penyuluhan dan tahap evaluasi untuk melihat sejauh mana keberhasilan dari program kegiatan yang sudah dilakukan dengan tujuan untuk perbaikan kembali.

\section{B. PENGERTIAN MANAJEMEN BIMBINGAN PENYULUHAN ISLAM}

Manajemen secara etimologi berasal dari kata bahasa inggris yaitu kata kerja to manage yang berarti mengatur, ${ }^{1}$ sinonimnya antara lain to hand (mengurus), to control (memeriksa), to guide (memimpin). Dengan demikian secara bahasa manajemen berarti pengurusan, pengendalian, dan pemimpin. Manajemen juga berasal dari kata managio yaitu

${ }^{1}$ Fatah Syukur, Manajemen Pendidikan Berbasis pada Madrasah, (Semarang: Pustaka Rizki Putra, Cet. 1, 2011), h. 7 
pengurusan atau managiare atau melatih dalam mengatur langkah-langkah. Manajemen sering diartikan sebagai ilmu, kiat dan profesi.

Pengertian manajemen secara terminologi : "management is the attainmentof organizational goal in an effective and efficient manner throught planning, organizing, leading, and controlling organizational resources". Manajemen adalah pencapaian tujuan organisasi dengan suatu cara yang efisien dan efektif melalui perencanaan, pengorganisasian, kepemimpinan dan pengendalian sumber daya organisasi. ${ }^{2}$ Manajemen memiliki tiga arti. Pertama, sebagai pengelolaan, pengendalian atau penanganan. Kedua, perlakuan secara terampil untuk menangani sesuatu berupa skillful treatment. Ketiga, gabungan dari dua pengertian tersebut, yaitu yang berhubungan dengan pengelolaan suatu perusahaan, rumah tangga atau suatu bentuk kerja sama dalam mencapai tujuan tertentu. ${ }^{3}$ Buku Human Resource Management mendefinisikan manajemen dengan: Management is the process of efficiently achieving the objectives of the organization with and through people. To achieve is objective, management typically requires the coordination of several vital components that we call function. The primary functions of management that are required are planning, organizing, leading and controlling. ${ }^{4}$ Manajemen merupakan suatu sistem tingkah laku manusia yang koperatif dalam melaksanakan tugas dan tanggung jawabnya dengan kepemimpinan yang tertatur melalui usaha yang terus menerus dilandasi tindakan yang rasional. Inti dari manajemen adanya leadership yaitu kepemimpinan menggerakkan orang-orang mengikuti pemimpin. ${ }^{5}$

Manajemen merupakan sebuah kegiatan, pelaksanaannya disebut manajing dan orang yang melakukannya disebut manajer. Individu yang menjadi manajer menangani tugas-tugas

2 Richard M. Hodgetts Fred Luthans, Management International, ( New York: Mc. Graw Hill, 1991) h. 5

3 Yayat M. Herujito, Dasar-Dasar Manajemen, (Jakarta: PT. Grasindo, 2004), h. 1.

${ }^{4}$ David A. Decenzo and Stephen P. Robbins, Human Resource Management, (New York: John Wiley \& Sons, Inc. 1999), h. 5

5 Saiful Sagala, Manajemen Strategik dalam Peningkatan Mutu Pendidikan, (Bandung: Alfabeta, 2007), h. 50 
baru yang seluruhnya bersifat manajerial. ${ }^{6}$ Manajemen adalah proses perencanaan, pengorganisasian, pengarahan dan pengawasan usaha-usaha para anggota organisasi dan penggunaan sumber daya-sumber daya organisasi lainnya agar mencapai tujuan organisasi yang telah ditetapkan. ${ }^{7}$ Manajemen pada hakikatnya berkenaan dengan cara-cara pengelolaan suatu lembaga agar supaya lembaga tersebut efisien dan efektif. ${ }^{8}$ Suatu lembaga dikatakan efisien apabila investasi yang ditanamkan di dalam lembaga tersebut sesuai dan memberikan profit sebagaimana yang diharapkan. Selanjutnya, suatu institusi akan efektif apabila pengelolaannya menggunakan prinsip prinsip yang tepat dan benar sehingga berbagai kegiatan di dalam lembaga tersebut dapat mencapai tujuan sebagaimana yang telah direncanakan.

Penjelasan di atas dapat kita pahami bahwa definisi manajemen adalah sebuah proses efisien untuk mencapai tujuan organisasi dan pelibatan individu. Guna mencapai tujuan ini, manajemen secara khusus membutuhkan koordinasi dari beberapa komponen penting yang kita sebut fungsi. Fungsi penting dari manajemen yang diperlukan adalah planning, organizing, leading, dan controlling. Manajemen merupakan seni untuk mengatur proses pemanfaatan sumber daya manusia dan sumber-sumber lainnya secara efektif dan efisien untuk tujuan tertentu, dan dalam mencapai tujuan tersebut kita tidak bergerak sendiri akan tetapi membutuhkan bantuan orang lain. Dapat juga kita simpulkan bahwa: (1) manajemen merupakan usaha atau tindakan ke arah pencapaian tujuan, (2) manajemen merupakan sistem kerja sama, (3) manajemen melibatkan secara optimal kontribusi orang-orang, dana fisik, dan sumber-sumber lainnya.

Sedangkan kata bimbingan secara etimologis merupakan terjemahan dari kata guidance berasal dari kata kerja to guide yang mempunyai arti menunjukkan, membimbing, menuntun ataupun membantu. Secara umum bimbingan dapat diartikan sebagai suatu bantuan atau tuntunan. Namun, meskipun demikian tidak

6 George R. Terry, Prinsip-Prinsip Manajemen, (Jakarta: Bumi Aksara, 2009),h. 9

7 T. Hani Handoko, Manajemen, Edisi 2, (Yogyakarta: BPFE Yogyakarta, 2003),h. 8

8 H.A.R. Tilaar, Membenahi Pendidikan Nasional, (Jakarta: PT. Rineka Cipta, 2002), h.10 
berarti semua bantuan atau tuntutan adalah bimbingan. ${ }^{9}$ Bimbingan merupakan suatu proses pemberian bantuan yang terus menerus dan sistematis dari pembimbing kepada terbimbing agar tercapai pemahaman diri, penerimaan diri, pengarahan diri dan perwujudan diri dalam mencapai tingkat perkembangan yang optimal dan penyesuaian diri dengan lingkungan. ${ }^{10}$ Bimbingan adalah bantuan yang diberikan oleh seseorang baik laki-laki maupun perempuan yang memiliki pribadi yang baik dan pendidikan yang memadai, kepada seseorang (individu) dari setiap umur untuk membantunya mengembangkan aktivitas-aktivitas hidupnya sendiri mengembangkan arah pandangannya sendiri, membuat pilihan sendiri, dan memikul bebannya sendiri. ${ }^{11}$

Bimbingan juga diartikan suatu proses bantuan yang diberikan pada siswa dengan memperhatikan kemungkinankemungkinan dan kenyataan tentang adanya kesulitan yang dihadapinya dalam rangka perkembangannya yang optimal, sehingga dapat memahami diri, mengarahkan diri dan bertindak serta bersikap sesuai dengan tuntutan dan keadaan lingkungan sekolah, keluarga, dan masyarakat. ${ }^{12}$ Miller berpendapat bimbingan adalah sebuah proses bantuan terhadap individu untuk mencapai pemahaman dan pengarahan diri yang dibutuhkan untuk melakukan penyesuaian diri secara maksimal kepada sekolah, keluarga serta masyarakat. ${ }^{13}$ Sementara itu ada juga yang memberikan difinisi bahwa bimbingan adalah bantuan yang diberikan kepada individu untuk mengatasi kesulitankesulitan di dalam kehidupannya supaya itu dapat mencapai kesejahteraan hidupnya atau dengan kata lain, bimbingan adalah bantuan yang diberikan seseorang dalam usaha memecahkan

${ }_{9}^{9}$ Hallen A, Bimbingan dan Konseling, (Jakarta: Ciputat Pers, Cet. 3, 2005), h. 3

10 Eddy Hendrarno, Bimbingan dan Konseling, (Semarang: Swadaya Manunggal, Cet. 3, 2003), h. 23

11Tohirin, Bimbingan dan Konseling di Sekolah dan Madrasah (Berbasis Integrasi), (Jakarta: PT Raja Grafindo Persada, Cet. 6, 2014), h.17

12Murniati, Pengantar Bimbingan dan Konseling, (Jakarta: Grafindo Pustaka Utama, 1992), h.40

13 I.Djumhur dan Moch Surya, Bimbingan dan Penyuluhan di Sekolah, (Bandung, CV Bina Ilmu,1995), h.26 
masalah-masalah yang dihadapinya. ${ }^{14}$ Dalam keterangan yang lain menyatakan bimbingan adalah suatu proses pemberian bantuan yang terus menerus dan sistematis dari pembimbing kepada orang yang dibimbing agar tercapai kemandirian dalam pemahaman diri, penerimaan diri dan pengarahan serta perwujudan diri dalam mencapai tingkat perkembangan yang optimal dan penyesuaian diri dengan lingkungan. ${ }^{15}$

Berdasarkan pendapat di atas dapat diketahui bahwa tidak adanya perbedaan yang menunjukkan pengertian bimbingan diantara para pakar tersebut, akan tetapi saling melengkapi yaitu adanya kesamaan unsur bantuan atau usaha pemberian bantuan yang diberikan sekelompok orang atau individu agar mampu memecahkan masalah-masalah tertentu yang dilakukan secara langsung atau dengan cara yang sesuai dengan keadaan klien, sehingga klien sanggup untuk mengemukakan isi hatinya secara bebas yang bertujuan agar klien dapat mengenal dirinya sendiri, menerima diri sendiri dan menerapkan dirinya sendiri dalam proses penyesuaian dengan lingkungannya serta dapat berkembang baik dan optimal dalam lingkungannya.

Penyuluhan menurut bahasa berasal dari terjemahan bahasa inggris yaitu "Counseling" yang berarti pemberian nasehat, penyuluhan dan penerangan. Maksudnya adalah seseorang yang memberikan nasehat terhadap orang lain yang membutuhkan penanganan untuk memecahkan masalahmasalah yang sedang dihadapi. Penyuluhan dalam arti umum adalah ilmu sosial yang mempelajari sistem dan proses perubahan pada individu serta masyarakat agar dapat terwujud perubahan yang lebih baik sesuai dengan yang diharapkan. ${ }^{16}$ Penyuluhan adalah suatu proses pemberian bantuan baik kepada individu ataupun kelompok dengan mengunakan metodemetode psikologis agar individu atau kelompok dapat keluar dari masalah dengan kekuatan sendiri, baik secara preventif,

14 Abu Ahmadi dan Ahmad Rohani H.M, Bimbingan dan Konseling di Sekolah, (Jakarta, PT. Rineka

Cipta, 1991), h.3

15 Mohammad Surya, Dasar-Dasar Penyuluhan (Caunseling), (Jakarta: P2LPTK. Dirjen Dikti,2008), h. 62-63

${ }^{16}$ Lucie Setiana, Teknik Penyuluhan dan Pemberdayaan Masyarakat, (Jakarta: Pustaka Pelajar, 2004)h. 2 
kuratif, korektif maupun development. ${ }^{17}$ Penyuluhan menurut Arifin adalah hubungan timbal balik antara dua individu, dimana yang seorang (penyuluh) berusaha membantu yang lain (klien) untuk mencapai pengertian tentang dirinya sendiri dengan hubungannya dalam masalah yang dihadapi pada saat itu dan mungkin pada waktu yang akan datang. ${ }^{18}$

Berdasarkan pendapat para ahli di atas dapat diketahui penyuluhan adalah merupakan salah satu teknik dalam pelayanan bimbingan dimana proses pemberian bantuan itu berlangsung melalui wawancara dalam serangkaian pertemuan langsung dan tatap muka antara pembimbing atau konselor dengan klien dengan tujuan agar klien mampu memperoleh pemahaman yang lebih baik terhadap dirinya untuk mengembangkan potensi yang dimilikinya kearah perkembangan yang optimal, sehingga ia dapat mencapai kebahagiaan pribadi dan kemanfaatan sosial dan mengerti terhadap masalah yang dihadapi pada saat itu dan mungkin pada waktu yang akan datang.

Dengan demikian manajemen bimbingan penyuluhan islam dapat diartikan sebagai suatu proses dengan perencanaan, pengorganisasian, pelaksanaan dan pengawasan yang optimal dalam rangka mencapai tujuan bimbingan penyuluhan islam yang efektif dan efisien. Manajemen pelayanan bimbingan penyuluhan islam adalah proses perencanaan, pengorganisasian, pengarahan dan pengawasan aktivitas-aktivitas pelayanan bimbingan dan konseling dan penggunaan sumber daya-sumber daya lainnya untuk mencapai tujuan yang telah ditetapkan. Kegiatan bimbingan penyuluhan islam dapat mencapai hasil yang efektif bilamana dari adanya program yang disusun dengan baik. Program yang baik tidak akan tercipta, terselenggara dan tercapai apabila tidak memiliki suatu sistem pengelolaan (manajemen) yang bermutu, dalam arti dilakukan secara jelas, sistematis dan terarah.

17 Isep Zainal Arifin, Bimbingan Penyuluhan islam, (Jakarta: Raja Grafindo Persada, 2009) ,h. 50

18 Bimo Walgito. Bimbingan dan Penyuluhan di Sekolah, (Yogyakarta: Andi Offset, 1900), h.5 


\section{DASAR BIMBINGAN PENYULUHAN ISLAM}

Bimbingan penyuluhan Islam yang dilakukan di masyarakat merupakan suatu kegiatan yang memiliki kemanfaatan dan nilai strategis dalam menjalankan fungsi untuk memperlancar pelaksanaan pembangunan moral dan budaya bangsa khususnya perorangan dengan bingkai bahasa negara, bangsa dan agama. Pedoman dasar penggunaan metode penyuluhan agama Islam sudah termaktub dalam Al-Qur'an dan Hadits Rasulullah SAW. Dalam Al-Qur'an dasar bimbingan penyuluhan islam ini disebutkan sebagai berikut:

1. Al-Qur'an surat An-Nahl ayat 125:

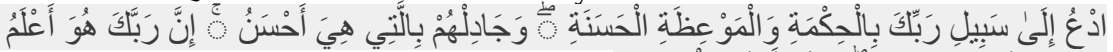

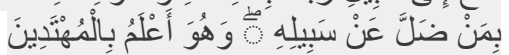

Terjemahannya: Serulah (manusia) kepada jalan Tuhan-mu dengan hikmah (perkataan yang tegas dan benar yang dapat membedakan antara yang hak dengan yang bathil) dan pelajaran yang baik dan bantahlah mereka dengan cara yang baik Sesungguhnya Tuhanmu Dialah yang lebih mengetahui tentang siapa yang tersesat dari jalan-Nya dan Dialah yang lebih mengetahui orang-orang yang mendapat petunjuk (Qs. An-Nahl: 125).

2. Al-Qur'an surat Al-Imran 104

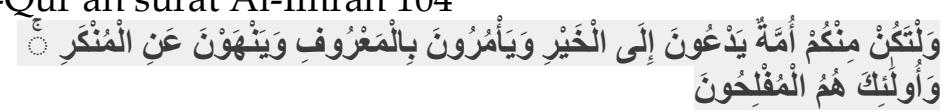

Terjemahannya: Dan hendaklah ada di antara kamu segolongan umat yang menyeru kepada kebajikan, menyuruh kepada yang ma'ruf dan mencegah dari yang munkar merekalah orang-orang yang beruntung (Qs AlImran :104).

\section{Hadist Rasulullah Saw}

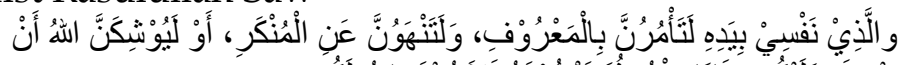

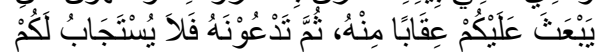

Terjemahannya: Dari Hudzaifah ra, dari nabi Saw, beliau bersabda " Demi dzat yang jiwaku berada dalam genggaman-Nya, seharusnyalah kalian menyuruh untuk berbuat baik dan mencegah dari perbuatan yang munkar. Jika tidak, sungguh Allah akan menurunkan siksa kepada 
kalian, kemudian kalian berdo'a kepada-Nya, tetapi Ia tidak mengabulkan do'amu." (HR. Tirmidziy).

Berdasarkan keterangan dari ayat dan hadits di atas menunjukkan kepada kita adanya seruan agar ada satu golongan atau kelompok dari umat manusia untuk memberikan suatu bimbingan kepada orang atau kelompok lain yakni berupa ajaran Islam agar berbakti kepada Allah dan berbuat ma'ruf, artinya segala perbuatan yang mendekatkan kita kepada Allah. Berdasarkan dalil-dalil tersebut, mengandung makna bahwa memberikan bimbingan kepada orang lain adalah hukumnya wajib. Firman Allah SWT dan sabda Nabi SAW tersebut juga menjelaskan agar mencegah perbuatan mungkar atau berbuat yang melanggar atau tidak sesuai dengan agama, dengan menggunakan cara yang bijaksana, nasehat yang baik dan berdebat dengan cara yang baik. Bimbingan penyuluhan Islam merupakan aspek dakwah islamiyah, dimana bimbingan penyuluhan Islam merupakan bantuan atau pertolongan yang mempunyai persoalan-persoalan rohaniah. Dakwah Islam merupakan suatu usaha untuk mengadakan pembinaan Islam dalam segala seginya, yaitu segi ibadah, segi aqidah, segi muamalah dan segi rohani. Berdasarkan firman Allah dan Sunnah Rasulullah tersebut, dapat disimpulkan bahwa prinsipprinsip bimbingan penyuluhan Islam (dakwah Islam) tidaklah menunjukkan kekakuan (terpancang dalam satu atau dua metode saja) akan tetapi selalu menampakkan kesesuaian. Perintah dakwah dalam agama Islam tidak mengharuskan secepatnya berhasil dengan satu atau dua metode saja, namun berbagai metode atau cara harus dikerjakan sesuai dengan keadaan objek dakwah, kemampuan masing-masing penyuluh agama Islam atas kebijaksanaannya masing-masing dan lain sebagainya.

\section{TUJUAN MANAJEMEN BIMBINGAN PENYULUHAN ISLAM}

Hal pertama yang perlu kita pahami sebelum mengetahui tujuan manajemen bimbingan penyuluhan islam adalah terlebih dahulu memahani tujuan dari bimbingan penyuluhan islam. Adapun tujuan tersebut adalah:

1. Tujuan Bimbingan penyuluhan islam Secara umum dan luas 
sebagai berikut:

a. Membantu individu dalam mencapai kebahagiaan pribadi

b. Membantu individu dalam mencapai kehidupan yang efektif dan produktif dalam masyarakat

c. Membantu individu dalam mencapai hidup bersama dengan individu yang lain

d. Membantu individu dalam mencapai harmoni antara citacita dan kemampuan yang dimiliki.

2. Tujuan bimbingan penyuluhan islam secara khusus adalah:

a. Memperkembangkan pengertian dan pemahaman diri dalam kemajuan dirinya;

b. Memperkembangkan pengetahuan tentang dunia kerja, kesempatan kerja, serta tanggung jawab dalam memilih suatu kesempatan kerja tertentu;

c. Memperkembangkan kemampuan untuk memilih, mempertemukan diri dan informasi tentang kesempatan yang ada secara bertanggung jawab;

d. Mewujudkan penghargaan terhadap kepentingan dan harga diri orang lain

Pada dasarnya penerapan manajemen dalam proses bimbingan penyuluhan islam adalah untuk mempermudah pencapaian suatu tujuan. Dalam upaya mencapai tujuan itu langkah pertama yang diperlukan adalah mengenal tujuan terlebih dahulu. Kejelasan pengenalan terhadap tujuan akan memberikan kepastian arah, memfokuskan arah, menjadi pedoman rencana dan keputusan, mempermudah pelaksanaan evaluasi terhadap kemajuan yang telah dicapai, termasuk mengidentifikasi faktor penghambat dan penunjangnya. John F.Mee memberikan sifat-sifat yang seharusnya terkandung dalam tujuan sehingga dapat mempermudah pemahaman tentang arti atau makna yang terkandung dalam tujuan, diantaranya tujuan harus ditentukan sebelum aktifitas organisasi dilakukan, dapat mengerti oleh semua personel yang terlibat dalam pelaksanaan aktivitas organisasinya, dinyatakan baik secara tertulis ataupun lisan, menjadi pegangan bagi para personel organisasi dalam proses pencapaiannya. Manajemen bimbingan penyuluhan islam bertujuan untuk mengembangkan diri konseli secara efektif dan efesien. Disamping sebagai pengembangan diri konseli manajemen bimbingan penyuluhan islam juga bertujuan untuk: 
1. Untuk Mengenal diri sendiri dan lingkungan konseli supaya dapat mengenali kekuatan dan kelemahan yang ada dalam dirinya sehingga dia dapat meyesuaikan dirinya dengan lingkungan. 2. Untuk menerima diri sendiri dan lingkungan secara positif dan dinamis. Diharapkan konseli dapat menerima keadaan yang ada pada dirinya. 3. Untuk dapat mengambil keputusan sendiri. Diharapkan seseorang dapat mandiri dalam mengambil keputusan sendiri untuk memenuhi kebutuhan dalam kebutuhannya dangan konsekuensi yang dapat dipertanggung jawabkan. 4. Untuk dapat mengarahkan diri sendiri. Diharapkan konseli dapat mangarahkan dirinya menurut bakat dan juga minat yang ada dalam dirinya. 5. Untuk dapat mewujudkan diri sendiri. Diharapkan konseli dapat merealisasikan dirinya dalam bentuk nyata sebagai sebuah wujud rasa percaya diri yang ada pada individu tersebut. ${ }^{19}$

Setiap organisasi mempunyai tujuan yang ingin dicapai, untuk mencapainya maka diperlukan adanya kegiatan manajemen sehingga tujuan dapat dicapai secara efektif dan efesien. Tujuan manajemen dilakukan secara sistematis adalah untuk mencapai hasil yang produktif, berkualitas, efektif dan efesien. ${ }^{20}$ Kegiatan manajemen bimbingan penyuluhan islam dikatakan produktif apabila dapat menghasilkan keluaran baik secara kualitas dan kuantitas. Kualitas dari layanan bimbingan penyuluhan islam dapat dilihat dari tingkat kepuasan dari konseli yang mendapatkan layanan bimbingan penyuluhan islam. Sedangkan kuantitas dari layanan bimbingan penyuluhan islam dilihat dari jumlah konseli yang mendapat layanan bimbingan penyuluhan islam. Efektif berarti kesesuaian antara hasil yang dicapai dengan tujuan, keefektifan dari layanan bimbingan penyuluhan islam adalah melihat dari ketercapaian layanan bimbingan penyuluhan islam yaitu konseli mampu mengembangkan dirinya secara optimal. Sedangkan efesien apabila kesesuaian antara sumber daya dengan keluaran atau penggunaan sumber dana yang minimal dapat dicapai tujuan yang diharapkan. Layanan bimbingan penyuluhan islam dapat dinyatakan efesien apabila tujuan bimbingan penyuluhan islam

19 Syahril \& Riska Ahmad, Pengantar Bimbingan dan Konseling ,( Padang: Angkasa Raya, 1990), h.86

20 Sugiyo, Komunikasi Antar Pribadi, (Semarang: Unnes Press, 2012), h. 27 
yaitu pengembangan diri konseli dapat segera dicapai dengan penggunaan sumber daya yang sedikit. Tujuan-tujuan manajemen bimbingan penyuluhan islam ini dapat dicapai secara efektif dan efisien apabila memenuhi prinsip-prinsip manajemen.

\section{E. PRINSIP-PRINSIP MANAJEMEN BIMBINGAN PENYULUHAN ISLAM}

Manajemen Bimbingan Penyuluhan Islam perlu memperhatikan prinsip-prinsip manajemen agar tujuan dari manajemen dapat tercapai, prinsip dalam pengelolaan manajemen yaitu (1) prinsip efisiensi dan efektivitas, dimana fungsi manajemen dilakukan dengan mempertimbangkan sarana prasarana, keadaan dan kemampuan organisasi agar relevan dengan tujuan yang dicapai; (2) prinsip pengelolaan, dimana suatu manajemen dilakukan secara sistematik dari perencanaan, pengorganisasian, pengarahan dan pengawasan; (3) prinsip pengutamaan tugas pengelolaan, dimana seorang manajer bertanggung jawab dalam melaksanakan kegiatan manajemen, baik pelayanan internal maupun eksternal; (4) prinsip kepemimpinan yang efektif, dimana seorang manajer harus memiliki sifat yang bijaksana dalam mengambil suatu keputusan dan mampu berhubungan baik dengan semua personel di dalam organisasi tersebut; (5) prinsip kerjasama, kerjasama didasarkan pada pengorganisasian. Pengorganisasian manajemen terkait dengan melaksanaan tugas sesuai dengan keahlian dan tugas masing-masing personil. ${ }^{21}$ Pendapat ahli yang lain menyatakan prinsip-prinsip manajemen meliputi: (1) efesiensi adalah kegiatan yang dilakukan dengan modal yang minimal dapat memberikan hasil yang optimal; (2) efektifitas adalah apabila terdapat kesesuaian antara hasil yang dicapai dengan tujuan; (3) pengelolaan adalah dalam aktivitas manajemen seorang manajer harus mengelola sumber daya yang ada baik sumber daya manusia maupun non manusia; (4) mengutamakan tugas pengelolaan artinya seorang manajer harus mengutamakan tugas manajerialnya dibandingkan tugas yang lain; (5) kerjasama adalah seorang manajer harus mampu menciptakan suasana

21 Hikmat, Manajemen Pendidikan, (Bandung: Pustaka Setia, 2009), h. 30 
kerjasama dengan berbagai pihak; dan (6) kepemimpinan yang efektif. ${ }^{22}$

Dari kedua pendapat di atas dapat diambil kesimpulan bahwa prinsip-prinsip manajemen bimbingan penyuluhan islam adalah :

1. Efesien dan efektif, artinya kesesuaian hasil layanan dengan tujuan yang ingin dicapai dari layanan bimbingan penyuluhan islm dengan memanfaatkan fasilitas yang ada secara optimal.

2. Kepemimpinan yang efektif, artinya konselor perlu bersikap bijaksana dalam mengambil keputusan dan mampu berkoordinasi dengan konseli secara baik.

3. Kerjasama, artinya adanya hubungan kerjasama yang baik antar konselor dengan konseli.

4. Pengelolaan manajemen, sistematika manajemen dari mulai perencanaan, pengorganisasian, pengarahan, dan evaluasi.

Prinsip dasar yang harus diperhatikan dalam manajemen bimbingan penyuluhan islam adalah :

1. Perencanaan

Perencanaan adalah proses penentuan tujuan atau sasaran yang hendak dicapai dan menetapkan jalan dan sumber yang diperlukan untuk mencapai tujuan itu seefisien mungkin. Dalam setiap perencanaan selalu terdapat tiga kegiatan yang meskipun dapat dibedakan, tetapi tidak dapat dipisahkan antara satu dengan yang lainnya dalam proses perencanaan. Ketiga kegiatan itu adalah 1) perumusan tujuan adalah yang ingin dicapai, 2) pemilihan program untuk mencapai tujuan itu, 3) identifikasi dan pengerahan sumber yang jumlahnya selalu terbatas. ${ }^{23}$ Perencanaan merupakan kegiatan mengarahkan atau menggunakan sumber-sumber yang terbatas secara berdaya guna dan berhasil guna untuk mencapai tujuan yang telah ditetapkan. ${ }^{24}$ Dengan perencanaan ini diharapkan dapat dihindari penyimpangan sekecil mungkin dalam penggunaan.

Penyusunan program bimbingan penyuluhan islam didasarkan atas kebutuhan yang diperoleh dari

22 Sugiyo, Komunikasi Antar Pribadi, (Semarang: Unnes Press, 2012), h. 37

${ }^{23}$ Nanang Fatah, Landasan Manajemen Pendidikan, (Bandung: PT. Remaja Rosdakarya, 2004), h. 49

${ }^{24}$ Dewa Ketut Sukardi, Manajemen Bimbingan dan Konseling, (Bandung:CV Alfabeta, 2003), h. 4 
pengumpulan data. Penyusunan program bimbingan penyuluhan islam perlu didasarkan atas kebutuhankebutuhan nyata di lapangan. Untuk mengidentifikasi kebutuhan-kebutuhan tersebut perlu diadakan pengumpulan data, baik data primer maupun data sekunder dari dokumendokumen yang ada. ${ }^{25}$ Dalam perencanaan bimbingan penyuluhan islam pada suatu kantor atau lembaga maka ada beberapa aspek kegiatan penting yang perlu dilakukan yaitu: 1) Analisis kebutuhan dan permasalahan. 2) Penentuan tujuan program layanan bimbingan penyuluhan yang hendak dicapai. 3) Analisis situasi dan kondisi di lapangan. 4) Penentuan jenis-jenis kegiatan yang akan dilakukan. 5) Penetapan metode dan teknik yang akan digunakan dalam kegiatan. 6) Penetapan personil-personil yang akan melaksanakan kegiatan-kegiatan yang telah ditetapkan. 7) Persiapan fasilitas dan biaya pelaksanaan kegiatan kegiatan bimbingan penyuluhan yang direncanakan. 8) Perkiraan tentang hambatan-hambatan yang akan ditemui dan usahausaha apa yang akan dilakukan dalam mengatasi hambatanhambatan. ${ }^{26}$ Yang juga harus diperhatikan dalam merencanakan program bimbingan penyuluhan islam adalah faktor waktu, dalam perencanaan program bimbingan penyuluhan islam, konselor harus dapat mengatur waktu untuk menyusun, melaksanakan, menilai, menganalisis, dan menindaklanjuti kegiatan bimbingan penyuluhan islam yang dilakukan. Dengan adanya perencanaan yang tersusun dengan baik diharapkan program yang akan dilaksanakan menjadi sistematis.

2. Pengorganisasian

Pengorganisasian adalah tindakan mengusahakan hubungan-hubungan kelakuan yang efektif antara orangorang, sehingga mereka dapat bekerjasama secara efisien, dan memperoleh kepuasan pribadi dalam melaksanakan tugastugas tertentu, dalam kondisi lingkungan tertentu guna mencapai tujuan atau sasaran tertentu. Kegiatan administratif

25 Nana Syaodih Sukmadinata, Bimbingan Konseling dalam Praktek, (Bandung, Maestro, 2007), h.124

26 Ahmad Juntika Nurihsan dan Akur Sudiarto, Manajemen Bimbingan dan Konseling di Sekolah Dasar, (Jakarta: Grasindo, 2009), h. 2930 
manajemen bimbingan penyuluhan islam tidak berakhir setelah perencanaan tersusun, kegiatan selanjutnya adalah melaksanakan perencanaan tersebut secara operasional. Salah satu bentuk dari kegiatan administrasi manajemen dalam pelaksanaan disebut pengorganisasian. Pengorganisasian dalam bimbingan penyuluhan islam terdiri dari dua kegiatan yaitu mengelompokkan macam-macam pekerjaan atau pelayanan (grouping of the work) dan menetapkan hubungan antar organ, pekerjaan, individu yang terlibat dalam organisasi. 27

3. Pelaksanaan

Pelaksanaan adalah perwujudan dalam tindakan dari rencana yang telah digariskan guna mencapai tujuan atau target organisasi yang telah digariskan. Telah dijelaskan bahwa sebaik apapun rencana akan tetapi jika tidak diimplementasikan maka tidak akan ada gunanya. Di dalam melaksanakan suatu rencana maka manajer harus membuat penjadwalan aktivitas. Penjadwalan aktivitas mengacu kepada serangkaian dan waktu yang diperlukan dari aktivitas kerja sehingga proses transformasi dapat disempurnakan seefektif dan seefisien mungkin. ${ }^{28}$ Tugas pokok seorang konselor islam adalah melaksanakan pelayanan bimbingan penyuluhan islam yang mendukung terlaksananya fungsi-fungsi bimbingan penyuluhan islam. Secara garis besar tugas tersebut dapat dikelompokkan ke dalam kategori kegiatan pelayanan berikut: kegiatan yang mendukung fungsi pemahaman, pencegahan, pengentasan, kegiatan yang mendukung fungsi pemeliharaan dan pengentasan, kegiatan yang mendukung fungsi advokasi. ${ }^{29}$ Tugas seorang konselor islam adalah menyusun program, melaksanakan program bimbingan, evaluasi pelaksanaan bimbingan, analisis hasil pelaksanaan bimbingan, dan tindak lanjut dalam program bimbingan terhadap konseli yang menjadi tanggung jawabnya.

27 Fajar Santoadi, Manajemen Bimbingan dan Konseling Komprehensif, (Yogyakarta: Universitas Sanata Dharma, 2010), h. 16

${ }^{28}$ Kusnadi, dkk, Pengantar Manajemen (Konseptual dan Perilaku), (Malang: Universitas Brawijaya, 1999), h. 247

29 Sugiyo, Manajemen Bimbingan dan Konseling di Sekolah, (Semarang:Widya Karya, 2011), h. 39 


\section{Pengawasan}

Pengawasan adalah penemuan dan penerapan cara dan peralatan untuk menjamin bahwa rencana telah dilaksanakan sesuai dengan yang telah ditetapkan. ${ }^{30}$ Pengawasan mencakup kelanjutan tugas untuk melihat apakah kegiatan dilaksanakan sesuai dengan rencana. Pelaksanaan kegiatan dievaluasi dan penyimpangan-penyimpangan yang tidak diinginkan diperbaiki supaya tujuan-tujuan dapat tercapai dengan baik. ${ }^{31}$ Pengawasan atau juga biasa disebut dengan monitoring adalah kegiatan yang dilakukan untuk memantau proses dan perkembangan pelaksanaan program. Monitoring dilakukan untuk tujuan supervisi yaitu untuk mengetahui apakah sebuah program berjalan sebagaimana yang direncanakan, apa hambatan yang terjadi dan bagaimana cara mengatasi masalah tersebut. Dengan kata lain monitoring menekankan pada proses pada pemantauan pelaksanaan dan hasil monitoring digunakan sebagai umpan balik untuk penyempurnaan pelaksanaan program yang sedang dilaksanakan. Pengawasan penting dilaksanakan dalam pelayanan bimbingan penyuluhan islam supaya tidak terjadi penyimpangan-penyimpangan dalam pelaksanaan pelayanan tersebut dan hasilnya dapat diukur. Pengawasan bimbingan penyuluhan islam ini dilaksanakan oleh pimpinan kantor atau lembaga penyuluhan. Implementasi pengawasan ini dilaksanakan oleh pimpinan terhadap pelaksanaan pelayanan bimbingan penyuluhan islam yang dilakukan oleh konselor.

5. Evaluasi

Evaluasi merupakan suatu proses sistematis dalam mengumpulkan, menganalisis, dan menginterpretasikan informasi untuk mengetahui tingkat keberhasilan suatu program dengan kriteria tertentu untuk keperluan pembuatan keputusan. Evaluasi menekankan pada hasil (out put). Konsekuensinya, evaluasi baru dapat dilakukan jika suatu program sudah berjalan satu periode, sesuai dengan tahapan sasaran yang dirancang. Evaluasi juga bisa dikatakan aktifitas untuk meneliti dan mengetahui sampai dimana

${ }^{30}$ T. Hani Handoko, Manajemen, (Yogyakarta: BPFE Yogyakarta, 2003), h. 25

31 George R Terry, Prinsip-Prinsip Manajemen, Alih Bahasa J. Smith D.F.M, (Jakarta: Bumi Aksara, 2006), h. 17-18 
pelaksanaan yang dilakukan di dalam proses keseluruhan organisasi mencapai hasil sesuai dengan rencana atau program yang telah ditetapkan. ${ }^{32}$ Dalam melakukan proses evaluasi adalah dengan melakukan penelaahan kebutuhan yang dapat membantu kita untuk mengetahui apa yang seharusnya kita kerjakan untuk menutup kesenjangan, yakni pada awal kegiatan, yang menjadi dasar untuk menyusun program, evaluasi juga membantu kita untuk mengetahui apa yang harus kita lakukan pada saat program sedang berlangsung. Evaluasi membantu untuk membuat sesuatu lebih baik karena berkat hasil-hasil evaluasilah dapat diambil tindakan tertentu. Dalam pelaksanaan evaluasi ada beberapa hal yang harus dilakukan yaitu: penentuan fokus dan tujuan evaluasi, pengembangan komponen dan indikator, rancangan pengumpulan data dan pengembangan instrumen, penyusunan rencana kerja. Fungsi evaluasi bimbingan penyuluhan islam yaitu memberikan umpan balik (feed back) kepada konselor untuk memperbaiki atau mengembangkan program bimbingan penyuluhan islam kedepannya.

Aspek kegiatan evaluasi program kegiatan bimbingan penyuluhan islam ada dua macam yaitu evaluasi proses (formatif) dan dapat berupa evaluasi hasil (sumatif). ${ }^{33}$ Penilaian proses dimaksudkan untuk mengetahui sampai sejauh mana keefektifan pelayanan bimbingan penyuluhan dilihat dari prosesnya, sedangkan penilaian hasil dimaksudkan untuk memperoleh informasi keefektifan pelayanan bimbingan penyuluhan dilihat dari hasilnya. Aspek yang dinilai baik proses maupun hasil antara lain: 1) kesesuaian antara program dengan pelaksanaan; 2) keterlaksanaan program; 3) hambatan-hambatan yang dijumpai; 4) dampak pelayanan bimbingan penyuluhan terhadap kegiatan keseharian konseli; 5) respon konseli, lingkungan, keluarga konseli, dan masyarakat terhadap pelayanan bimbingan penyuluhan; 6) perubahan kemajuan konseli dilihat dari pencapaian tujuan pelayanan bimbingan penyuluhan, pencapaian tugas-tugas perkembangan, dan

32 Zubaidi, Pendidikan Berbasis Masyarakat; Upaya Menawarkan Solusi Terhadap Problem Sosial, (Yogyakarta: Pustaka Pelajar, 2006), h. 161

33 Ahmad Juntika Nurihsan dan Akur Sudiarto, Manajemen Bimbingan dan Konseling di SMP, (Jakarta: Grasindo, 2005), h. 45 
hasil kegiatan konseli dan perubahan tingkah laku konseli setelah melaksanakan bimbingan penyuluhan dalam kehidupannya di masyarakat. Hasil bimbingan penyuluhan berupa diskripsi tentang aspek-aspek yang dievaluasi yang mencerminkan sejauh mana proses penyelenggaraan pelayanan atau pendukung memberikan sesuatu yang berharga bagi kemajuan dan perkembangan dan atau memberikan bahan atau kemudahan untuk kegiatan pelayanan terhadap konseli. Pelaksanaan evaluasi program ditempuh melalui langkah-langkah berikut: merumuskan masalah atau mengembangkan atau menyusun instrumen pengumpul data, mengumpulkan dan menganalisis data, melakukan tindak lanjut (follow up).

\section{F. FUNGSI MANAJEMEN BIMBINGAN PENYULUHAN ISLAM}

Fungsi bimbingan penyuluhan islam yang dilakukan oleh seseorang dalam rangka memberikan bantuan kepada orang lain yang mengalami kesulitan-kesulitan rohaniah dalam lingkungan hidupnya agar seseorang tersebut mampu mengatasinya sendiri karena timbulnya kesadaran ataupun penyerahan diri terhadap kekuasaan Tuhan Yang Maha Esa. Fungsi bimbingan secara umum adalah sebagai fasilitator dan motivator klien dalam upaya mengatasi dan memecahkan problem kehidupan klien dengan kemampuan yang ada pada dirinya sendiri. Fungsi bimbingan penyuluhan islam antara lain sebagai berikut:

1. Menjadi pendorong (motivator) bagi klien yang terbimbing timbul semangat dalam menempuh kehidupan;

2. Menjadi pemantap (stabilitator) dan penggerak (dinamisator) untuk mencapai tujuan yang dikehendaki;

3. Menjadi pengarah (direktif) bagi pelaksanaan program bimbingan agar sesuai dengan pertumbuhan dan perkembangan klien serta melihat bakat dan minat yang berhubungan dengan cita-cita yang ingin dicapainya. ${ }^{34}$

${ }^{34}$ Arifin, dan Kartikawati, Materi Pokok Bimbingan Dan Konseling (Jakarta: Direktorat Jenderal Pembinaan Kelembagaan Agama Islam 2005), h. 7 
Fungsi dalam manajemen merupakan tugas-tugas tertentu yang harus dilaksanakan yang dapat memberikan persyaratan pelaksanaan suatu pekerjaan yang harus diperhatikan oleh seseorang atau suatu sistem artinya dengan pelaksanaan fungsi- fungsi tersebut maka pekerjaan akan diselesaikan dengan hasil yang memuaskan. Fungsi manajemen bimbingan penyuluhan islam secara tersirat yaitu:

\section{Perencanaan}

Perencanaan ini dilakukan sebagai langkah awal untuk meningkatkan kualitas manajemen bimbingan penyuluhan islam agar mempunyai mutu yang lebih baik sehingga akan dapat membantu menyokong tujuan dari layanan bimbingan penyuluhan islam. Perencanaan juga merupakan proses penetapan tujuan kegiatan dan memilih cara atau strategi yang tepat untuk mencapai tujuan. Karena itu dalam menjalankan aktifitas manajemen yang baik diperlukan suatu perencanaan yang matang dan pasti. Karena itu proses perencanaan hendaknya menyuguhkan informasi yang lengkap menyeluruh bagi semua personel yang terlibat, terutama tentang:

a. Tujuan-tujuan dan cara-cara atau strategi mencapai tujuan

b. Pedoman bagi semua personel yang terlibat dalam menjalankan tugas-tugas suatu organisasi.

c. Alat pengawasan terhadap pelaksanaan program

d. Penggunaan segala sumber daya yang dimiliki organisasi secara efisien

e. Batas-batas kewenangan dan tanggung jawab setiap personel pelaksanaan organisasi sehingga dapat meningkatkan kinerja dan kerjasama antar personel

f. Kriteria atau tolok ukur prestasi organisasi, baik berkenaan dengan program, pelaksanaan maupun out put atau hasil yang harus diperoleh.

Kegiatan perencanaan bimbingan penyuluhan islam meliputi (1) identifikasi kebutuhan (need assesment), (2) analisis situasi, (3) merumuskan dan meninjau alternatif pemecahan masalah, dan (4) memilih alternatif 
pemecahan masalah. Sedangkan manfaat dari perencanaan program bimbingan penyuluhan islam adalah 1)Adanya kejelasan arah pelaksanaan program bimbingan penyuluhan islam 2)Adanya kemudahan mengontrol dan mengevaluasi kegiatan bimbingan penyuluhan islam yang dilakukan 3)Terlaksananya program kegiatan bimbingan penyuluhan islam secara lancar, efektif dan efesien. ${ }^{35}$ Dalam tahap penyusunan program perlu dipertimbangkan 1) perumusan masalah yang dihadapi 2) perumusan tujuan yang jelas; dan 3) perumusan inventaris berbagai fasilitas yang ada, personel, dan anggaran biaya.

Dari berbagai pendapat di atas maka dapat disimpulkan bahwa kegiatan perencanaan terdiri dari:

a. Analisis kebutuhan

b. Analisis situasi dan kondisi

c. Penentuan tujuan

d. Penentuan jenis kegiatan

e. Penentuan waktu dan tempat kegiatan

f. Penentuan fasilitas dan anggaran biaya

2. Pengorganisasian

Pengorganisasian yang baik ditandai oleh adanya dasar dan tujuan organisasi, personel yang matang, pengorganisasian berguna untuk menciptakan hubungan administratif yang jelas dan tegas, pemahaman akan tugas, tanggung jawab dan wewenangnya serta mengetahui peran dalam hubungan kerja sama yang harmonis. Pengorganisasian kegiatan bimbingan penyuluhan islam memiliki peran kunci dalam menunjang keberhasilan pelaksanaan program bimbingan penyuluhan islam. Hal ini dikarenakan pengorganisasian yang tepat dapat memberikan arah dan pedoman posisi masing-masing pelaksana bimbingan penyuluhan islam. Adanya pembagian tugas yang jelas, profesional, dan proposional membuat setiap petugas dapat memahami tugasnya dan menumbuhkan hubungan kerjasama yang baik. Selain itu, pengaturan tugas yang tepat dengan kemampuan dan karakteristiknya membuat tidak terjadi

${ }^{35}$ Achmad Juntika Nurihsan, Bimbingan dan Konseling "Dalam Berbagai Latar dan Kehidupan" (Bandung: Rineka Cipta, 2006), h. 27 
kesalahpahaman.

Seorang konselor dalam pengorganisasian perlu memperhatikan hal-hal berikut :

a. Semua personel harus dihimpun dalam suatu wadah sehingga terwujud dalam kesatuan untuk memberikan layanan bimbingan penyuluhan islam.

b. Melakukan persamaan persepsi dalam melakukan layanan meliputi mekanisme kerja, pola kerja, dan prosedur kerja.

c. Adanya perincian yang jelas tentang tugas, tanggung jawab dan wewenang masing-masing.

Adapun yang menjadi kegiatan konselor dalam pengorganisasian pada manajemen bimbingan penyuluhan islam adalah:

a. Sosialisasi cara kerja petugas bimbingan penyuluhan islam, berarti konselor harus memberitahukan program bimbingan penyuluhan islam dan cara kerja konselor dalam menjalankan program tersebut kepada stakeholder.

b. Pembagian tugas antar petugas bimbingan penyuluhan islam, berarti dalam organisasi bimbingan dan konseling perlu dibuat struktur organisasi sehingga diketahui wewenang dari masing-masing konselor, selain itu dalam pembagianini juga dilakukan pembagian sasaran kegiatan bimbingan penyuluhan islam.

c. Pelibatan dan koordinasi dengan stakeholder dalam kegiatan bimbingan penyuluhan islam.

d. Menciptakan hubungan kerjasama dengan stakeholder.

Manfaat pengorganisasian dalam manajemen bimbingan penyuluhan islam adalah:

a. Setiap personil menyadari tugas, peranan, kedudukan, wewenang dan tanggung jawab masingmasing.

b. Terhindar dari terjadinya tumpang tindih tugas diantara para personel bimbingan penyuluhan islam.

c. Terjadi mekanisme kerja secara baik dan teratur

d. Tercapai kelancaran, efesiensi dan efektifitas pelaksanaan program layanan bimbingan 
penyuluhan islam.

Implementasi pengorganisasian dari bimbingan penyuluhan islam tidak dapat dilaksanakan secara jelas dan sistematis apabila tidak diimbangi dengan organisasi yang baik. tanpa organisasi berarti tidak adanya suatu koordinasi, perencanaan, sasaran yang cukup jelas, serta kepemimpinan yang proporsional dan profesional.

3. Pelaksanaan

Pelaksanaan merupakan kegiatan yang paling utama dalam kegiatan manajemen, pelaksanaan menekankan pada kegiatan yang berhubungan langsung dengan orang lain dalam suatu organisasi. Artinya pelaksanaan merupakan upaya dalam mewujudkan perencanaan menjadi kenyataan dengan berbagai pengarahan. Pengarahan adalah fase manajemen yang terdiri dari kegiatan mengkoordinasi, mengontrol dan menstimulasi semua unsur agar berfungsi secara optimal.

Pelaksanaan bimbingan penyuluhan islam mengarah pada pelaksanaan program bimbingan penyuluhan islam yang telah direncanakan, hal ini terkait dengan layananlayanan bimbingan penyuluhan islam. Agar pelaksanaan dari layanan-layanan bimbingan penyuluhan islam dapat berjalan dengan lancar, konselor harus: a) mampu menciptakan suasana kerja yang kondusif. b) mensinkronkan antara tujuan bimbingan penyuluhan islam dengan tujuan petugas bimbingan penyuluhan islam. c)menciptakan hubungan yang harmonis. d) mengoptimalkan potensi petugas bimbingan penyuluhan islam. e) menempatkan petugas bimbingan penyuluhan islam sesuai dengan kemampuan dan karakteristiknya. Adapun implementasi pelayanan bimbingan penyuluhan islam dalam manajemen bimbingan penyuluhan islam adalah: a) layanan Orientasi; b) layanan Informasi; c) layanan Penempatan dan Penyaluran; d) layanan Pembelajaran; e) layanan Konseling Individual; f) layanan Konseling Kelompok; g) layanan Bimbingan individual; h) layanan Bimbingan kelompok. 


\section{Evaluasi}

Fungsi evaluasi bimbingan penyuluhan islam yaitu memberikan umpan balik kepada konselor untuk memperbaiki atau mengembangkan program bimbingan penyuluhan islam, memberikan informasi kepada konseli tentang perkembangan sikap dan perilaku atau tingkat ketercapaian tugas-tugas perkembangannya agar secara bersinergi dan berkolaborasi meningkatkan kualitas program bimbingan penyuluhan islam. Penilaian kegiatan bimbingan penyuluhan islam adalah segala upaya, tindakan atau proses untuk menentukan derajat kualitas kemajuan kegiatan yang berkaitan dengan pelaksanaan program bimbingan penyuluhan islam dengan mengacu pada kriteria atau patokan-patokan tertentu sesuai dengan program bimbingan penyuluhan islam. yang dilaksanakan. Kegiatan dalam evaluasi meliputi: a. menetapkan standar kinerja; b. mengukur kinerja; c. membandingkan prestasi kerja dengan standar yang ditetapkan; d. mengambil tindakan korektif saat ditemukan penyelewengan. ${ }^{36}$ Sedangkan proses evaluasi meliputi: a. recording (administrasi/ pencatatan); $b$. evaluasi (pengukuran dan penilaian hasil dan proses kerja serta kinerja organisasi); c. pengambilan langkah perbaikan dan pengembangan. ${ }^{37}$

Dari kedua pendapat di atas maka dapat diambil kesimpulan bahwa kegiatan dalam evaluasi meliputi :

a. Pencatatan hasil kerja dan kinerja organisasi

b. Menetapkan standar kinerja

c. Mengukur dan menilai hasil keja dan kinerja organisasi

d. Mengambil tindakan perbaikan dan pengembangan.

Kriteria atau patokan yang dipakai untuk menilai keberhasilan pelaksanaan program layanan bimbingan penyuluhan islam adalah mengacu pada terpenuhi atau

36 Sugiyo, Manajemen Bimbingan dan Konseling di Sekolah, (Semarang: Widya Karya, 2011), h. 47

37 Fajar Santoadi, Manajemen Bimbingan dan Konseling komprehensif, (Yogyakarta: Universitas sanata Dharma, 2010), h. 26 
tidaknya kebutuhan-kebutuhan konseli dan pihak-pihak yang terlibat, baik langsung maupun tidak langsung berperan membantu konseli dalam memperoleh perubahan perilaku dan pribadi kearah yang lebih baik. Dalam keseluruhan kegiatan layanan bimbingan penyuluhan islam, evaluasi atau penilaian diperlukan untuk memperoleh umpan balik terhadap keefektifan layanan bimbingan penyuluhan islam yang telah dilaksanakan. Dengan informasi ini dapat diketahui sampai sejauh derajat keberhasilan kegiatan layanan bimbingan penyuluhan islam.

Ada dua macam kegiatan penilaian program kegiatan bimbingan penyuluhan islam, yaitu penilaian proses dan penilaian hasil. Penilaian proses dimaksudkan untuk mengetahui sampai sejauh mana keefektifan layanan bimbingan penyuluhan islam dilihat dari prosesnya, sedangkan penilaian hasil dimaksudkan untuk memperoleh informasi keefektifan layanan bimbingan penyuluhan islam dilihat dari hasilnya.

Aspek yang dievaluasi baik proses maupun hasil antara lain:

1. Kesesuaian antara program dengan pelaksanaan.

2. Keterlaksanaan program.

3. Hambatan-hambatan yang dijumpai.

4. Dampak layanan bimbingan penyuluhan islam terhadap kegiatan konseli.

5. Respon konseli dan masyarakat terhadap layanan bimbingan penyuluhan islam.

6. Perubahan kemajuan konseli dilihat dari pencapaian tujuan layanan bimbingan penyuluhan islam dan pencapaian tugastugas perkembangan

7. Keberhasilan konseli setelah menyelesaikan, baik pada studi lanjutan maupun kehidupan di masyarakat.

\section{G. SIMPULAN}

Dari berbagai uraian di atas maka dapatlah dikemukakan beberapa kesimpulan peran manajemen dalam bimbingan penyuluhan islam, yaitu :

1. Manajemen bimbingan penyuluhan Islam membahas tentang bagaimana pengelolaan yang dilakukan oleh 
penyuluh dalam melaksanakan tugasnya;

2. penerapan manajemen dalam proses bimbingan penyuluhan islam adalah untuk mempermudah pencapaian suatu tujuan;

3. Manajemen bimbingan penyuluhan islam bertujuan untuk mengembangkan diri konseli secara efektif dan efesien;

4. Seorang konselor harus memahami prinsip-prinsip manajemen bimbingan penyuluhan islam;

5. Fungsi bimbingan secara umum adalah sebagai fasilitator dan motivator klien dalam upaya mengatasi dan memecahkan problem kehidupan klien dengan kemampuan yang ada pada dirinya sendiri

6. Fungsi manajemen bimbingan penyuluhan islam yaitu sebagai perancanaan, pengorganisasian, pelaksanaan dan evaluasi proses dari bimbingan penyuluhan islam.

\section{DAFTAR PUSTAKA}

Ahmadi, Abu dan Ahmad Rohani H.M, Bimbingan dan Konseling di Sekolah, Jakarta, PT. Rineka Cipta, 1991

Arifin, dan Kartikawati, Materi Pokok Bimbingan Dan Konseling,Jakarta: Direktorat Jenderal Pembinaan Kelembagaan Agama Islam 2005

Arifin, Isep Zainal, Bimbingan Penyuluhan islam, Jakarta: Raja Grafindo Persada, 2009

Decenzo David A., and Stephen P. Robbins, Human Resource Management, New York: John Wiley \& Sons, Inc. 1999

Djumhur, I. dan Moch Surya, Bimbingan dan Penyuluhan di Sekolah, Bandung, CV Bina Ilmu,1995

Fatah, Nanang, Landasan Manajemen Pendidikan, Bandung: PT. Remaja Rosdakarya, 2004

Hallen A, Bimbingan dan Konseling, Jakarta: Ciputat Pers, Cet. 3, 2005 
Handoko, T. Hani, Manajemen, Edisi 2, Yogyakarta: BPFE, 2003

Hendrarno, Eddy, Bimbingan dan Konseling, Semarang: Swadaya Manunggal, Cet. 3, 2003

Herujito, Yayat M., Dasar-Dasar Manajemen, Jakarta: PT. Grasindo, 2004

Hikmat, Manajemen Pendidikan, Bandung: Pustaka Setia, 2009

Kusnadi, dkk, Pengantar Manajemen (Konseptual dan Perilaku), Malang: Universitas Brawijaya, 1999

Murniati, Pengantar Bimbingan dan Konseling, Jakarta: Grafindo Pustaka Utama, 1992

Nurihsan, Ahmad Juntika dan Akur Sudiarto, Manajemen Bimbingan dan Konseling di SMP, Jakarta: Grasindo, 2005

-------, Manajemen Bimbingan dan Konseling di Sekolah Dasar, Jakarta: Grasindo, 2009

Nurihsan, Achmad Juntika, Bimbingan dan Konseling "Dalam Berbagai Latar dan Kehidupan" Bandung: Rineka Cipta, 2006

Richard M. Hodgetts Fred Luthans, Management International, (New York: Mc. Graw Hill, 1991

Sagala, Saiful, Manajemen Strategik dalam Peningkatan Mutu Pendidikan, Bandung: Alfabeta, 2007

Santoadi, Fajar, Manajemen Bimbingan dan Konseling komprehensif, Yogyakarta: Universitas sanata Dharma, 2010

Setiana, Lucie, Teknik Penyuluhan dan Pemberdayaan Masyarakat, Jakarta: Pustaka Pelajar, 2004

Sukardi, Dewa Ketut, Manajemen Bimbingan dan Konseling, Bandung:CV Alfabeta, 2003 
Sukmadinata, Nana Syaodih, Bimbingan Konseling dalam Praktek, Bandung, Maestro, 2007

Surya, Mohammad, Dasar-Dasar Penyuluhan (Caunseling), Jakarta: P2LPTK. Dirjen Dikti, 2008

Sugiyo, Manajemen Bimbingan dan Konseling di Sekolah, Semarang:Widya Karya, 2011

-----, Komunikasi Antar Pribadi, Semarang: Unnes Press, 2012

Syahril \& Riska Ahmad, Pengantar Bimbingan dan Konseling, Padang: Angkasa Raya, 1990

Syukur, Fatah, Manajemen Pendidikan Berbasis pada Madrasah, Semarang: Pustaka Rizki Putra, Cet. 1, 2011

Terry, George R, Prinsip-Prinsip Manajemen, Alih Bahasa J. Smith D.F.M, Jakarta: Bumi Aksara, 2009

Tilaar, H.A.R., Membenahi Pendidikan Nasional, Jakarta: PT. Rineka Cipta, 2002

Tohirin, Bimbingan dan Konseling di Sekolah dan Madrasah (Berbasis Integrasi), Jakarta: PT Raja Grafindo Persada, Cet. 6, 2014

Walgito, Bimo, Bimbingan dan Penyuluhan di Sekolah, Yogyakarta: Andi Offset, 1900

Zubaidi, Pendidikan Berbasis Masyarakat; Upaya Menawarkan Solusi Terhadap Problem Sosial, Yogyakarta: Pustaka Pelajar, 2006 
142 | Bimbingan Penyuluhan Islam, Vol. 1, No. 1 Januari-Juni 2019

Hamdi Abdul Karim Peran Manajemen dalam Bimbingan Penyuluhan Islam 